\title{
Intencje pielgrzymowania uczestników XXX, XXXI i XXXII Pieszej Pielgrzymki Skałecznej
}

\section{Pilgrimage intentions of XXX, XXXI and XXXII Skałeczna Walking Pilgrimage participants}

\begin{abstract}
Pilgrims take part in the pilgrimage with a particular purpose, a single or multiple intentions. Intention can be religious or secular. In this article we focus on individual intentions of pilgrims taking part in Skałeczna Walking Pilgrimage from Kraków to Jasna Góra in Częstochowa. Each pilgrim apart from individual intentions devotes his or her effort in the collective intentions of the whole pilgrimage. In recent years, late pope John Paul II played an important role in the collective intentions of pilgrimage from Kraków to Jasna Góra.

Results presented in this paper has been obtained from two sources. We collected 579 surveys between 2006 and 2008 and conducted a number of individual interviews.

Our results show that almost always pilgrims travel with religious intentions. Using an open question format, we found that majority of intentions were begging intentions (477 answers), grace intentions are the second most popular and were indicated in 172 answers. Penance intention has only been mentioned in 30 answers. Only a few pilgrims picked secular intentions. Our results clearly show that religious intentions are still the most popular one.
\end{abstract}

Keywords: intention, pilgrimage, Skałeczna Walking Pilgrimage, Jasna Góra, Kraków, John Paul II

\section{Wprowadzenie}

Wyruszając na szlak pątniczy pielgrzym podejmuje swój trud w określonym celu, w wybranej - zwykle jasno zdefiniowanej - intencji lub w wielu intencjach. 
Intencja rozumiana jako „(...) pragnienie, plan, dążenie zorientowane na jakiś cel, jakiś stan końcowy (...)” (Reber, Reber 2005: 289), „zamierzenie, motyw (...)” (Katechizm Kościoła Katolickiego 1994: 704), może przybrać charakter religijny ale i świecki. W niniejszym artykule skupiono się na indywidualnych intencjach pielgrzymów uczestniczących w Pieszej Pielgrzymce Skałecznej ${ }^{1}$ zmierzającej z Krakowa na Jasną Górę w Częstochowie. Należy jednak zaznaczyć, że stając się częścią wybranej pielgrzymki, pątnik podejmuje trud pątniczy nie tylko we własnej intencji czy też tych mu powierzonych, ale i w intencji przypisanej całej wspólnocie pątniczej. W szczególny sposób, w treść intencji przewodnich współczesnych krakowskich pielgrzymek wędrujących pieszo ku Jasnej Górze, wpisano postać Jana Pawła II. Działalność i charyzmat papieża - Polaka zdeterminował na lata charakter Pieszej Pielgrzymki Skałecznej. Zewnętrznym przejawem przywiązania, szacunku i miłości do Jego osoby oraz głoszonej przez Jana Pawła II nauki stała się m.in. główna intencja każdej pielgrzymki - za Ojca Świętego, Kościół i Ojczyznę oraz napis widniejący na tablicy pielgrzymkowej niesionej na czele grupy: Totus Tuus (...) w intencji OJCA ŚW. (ASk 1, Władyczanka 1993: 12, 17 , Jabłoński 1996: 44, www 1), (ryc. 1, fot. 1). Drugą krakowską wspólnotą pątniczą pielgrzymującą (od 1981 r.) na Jasną Górę „(...) w intencji Ojca św. i Ojczyzny” (Balon, Samsonowska 1996: 59, Gubała i in. 2002: 6, 14, wywiad 1) jest Piesza Pielgrzymka Krakowska (fot. 2). Zdaniem A. Baca, właśnie ta intencja zdeterminowała na lata jej liczebność oraz ciągłość funkcjonowania (wywiad 1). Od 2005 r. główną intencją modlitewną pielgrzymki była rychła beatyfikacja Jana Pawła II, w kolejnych latach - jego kanonizacja, duchowe wspieranie papieża Benedykta XVI, aktualnie papieża Franciszka oraz modlitwa w intencji Ojczyzny (www 2).

Choć podając w kwestionariuszu swe osobiste intencje pielgrzymi skałeczni bezpośrednio nie odwołują się do postaci Jana Pawła II, warto przypomnieć, że w roku 1981 bardzo wielu z nich wyruszyło na szlak w intencji Papieża. Dziękowano za uratowanie życia oraz modlono się o powrót do zdrowia Ojca Świętego postrzelonego 13 maja na Palcu św. Piotra w Rzymie ${ }^{2}$. Powyższe

1 Piesza Pielgrzymka Skałeczna to najstarsza (powstała w 1976 r.) i zarazem najmniejsza (licząca średnio około 250 osób) z aktualnie funkcjonujących pielgrzymek pieszych zmierzających corocznie w dniach od 16 do 22 lipieca z Krakowa na Jasną Górę w Częstochowie.

2 Jak podaje E. Szumska „(...) komu Ojciec podsunął mikrofon (...)” w trakcie pielgrzymki, pytając jako przewodnik o przyczynę pielgrzymowania (...) więcej niż połowa (...) osób wskazywała na intencję dziękczynną za uratowanie życia Jana Pawła II"; wywiad 2. 


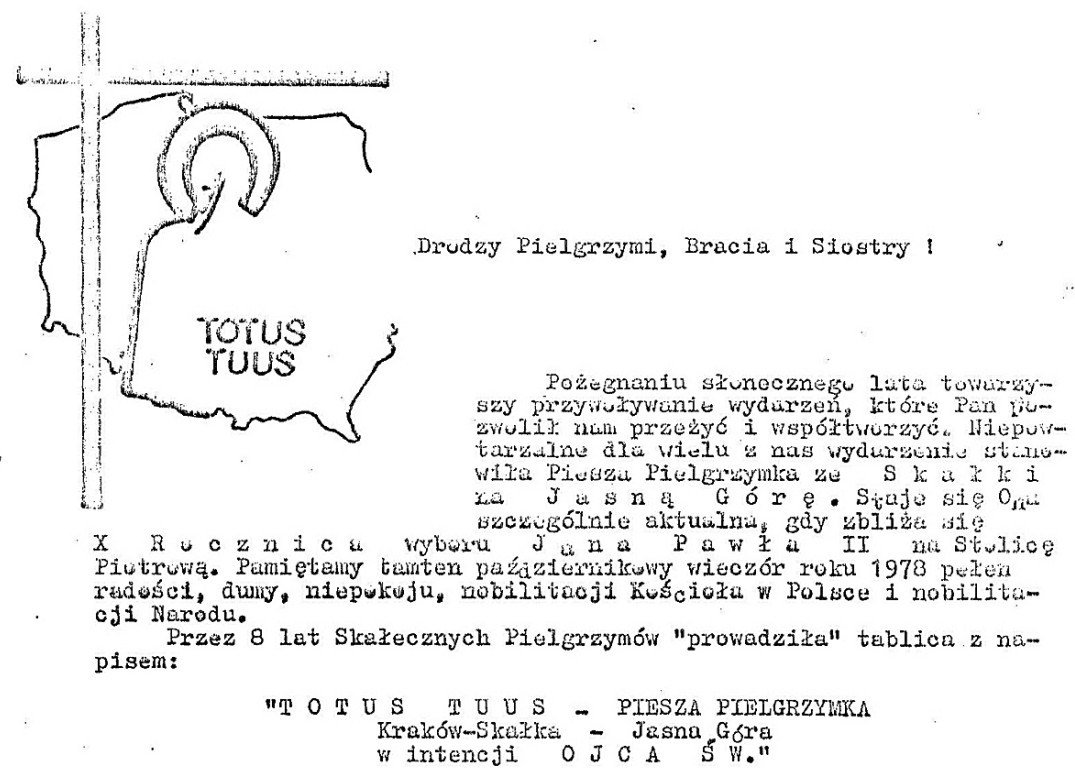

W tym ruku informowała o naszej paci tablica z histuryczna dedykacją: "Z serdecznym błogosiawieńgtvem Tarul Kardynax Wojtyła metropolita krakowakl 1.VII.1978 w Caegtochowie"

W dniu świętowania Jubileuszowego "Dnia Papiesklego", v swuich

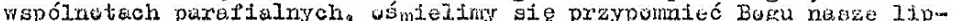
cowe dni mediltwy nós I warg i dziegowaé za Dar Jana Pawla JI als Kóscioza, świata i Narodu.

Na $S$ k a 1 c e zgromadziny sie 23 paździemika pray sexm cu Jasnogórakiej Hatki Koscioza, aby prosico delsze błogostavlone late dla Jana Pawla II.

$$
\begin{aligned}
& \text { gedz: } 10^{30}-\operatorname{lif}_{\mathrm{s}} \mathrm{z} \text { ś } w \text {. wintencji Piexwsego } \\
& \text { Pielgrzyma } 1 \text { nas - pielgrzymów } \\
& \text { godz. } 11^{45} \text { - Mudiitwa przy Irzyzia Spotkania } \\
& z \text { Janem Paw } \\
& \text { godz. } 12^{15} \text { - Braterskie spotkanie, agapa, wspomienia, }
\end{aligned}
$$

Pozostając w modlitownej wiezi, gerdecznie Was pozdravium i oczekuje.

$$
\begin{aligned}
& \text { W imieniu animatorów } \\
& \text { Rechanten fobmo Per DP }
\end{aligned}
$$

Ryc. 1. Zaproszenie do uczestników PPS na październikowe spotkanie popielgrzymkowe, w ramach którego świętowano X. rocznicę wyboru Jana Pawła II na Stolicę Apostolską (1988 r.)

Źródło: ASk 1. 
wydarzenie stało się bodźcem również dla wielu osób, które dołączyły do Pieszej Pielgrzymki Krakowskiej, która po raz pierwszy wyruszyła z Wawelu na Jasną Górę właśnie w 1981 r. (Gubała i in. 2002: 29).

\section{Metodologia badań}

Zaprezentowane $\mathrm{w}$ artykule dane dotyczące intencji pielgrzymowania pozyskano w ramach badań ankietowych, które przeprowadzono trzykrotnie w latach: 2006, 2007, 2008, uzyskując 579 kwestionariuszy (tab. 1). Powyższą technikę (ankietową) zastosowano $\mathrm{w}$ toku prowadzonych badań terenowych zrealizowanych w latach 2006-2013, w celu poznania społeczno-geograficznych uwarunkowań pieszego pielgrzymowania z Krakowa na Jasną Górę. Podmiotem prowadzonych badań byli uczestnicy Pieszej Pielgrzymki Skałecznej. Aby w jak największym stopniu ujednolicić warunki (środowiskowe, czasowe), w jakich respondenci udzielali odpowiedzi, badania zrealizowano w trakcie pielgrzymki. Ograniczenie wpływu czynników zewnętrznych, mogących w znaczący sposób rzutować na wypowiedzi badanych, pozwoliło analizować i interpretować uzyskane wyniki znając okoliczności (jednakowe dla wszystkich), w jakich pielgrzymi wypełniali kwestionariusz. Kierując się powyższą zasadą, badania przeprowadzono trzykrotnie w tym samym miejscu, w trzecim dniu trwania pielgrzymki. Skupienie badanych w jednym miejscu, umożliwiające bezpośrednie przekazanie i zebranie materiałów w środowisku pielgrzymów, kwalifikuje zastosowaną technikę ankietową do kategorii ankiet środowiskowych ${ }^{3}$. Kwestionariusze przekazane respondentom spełniały warunki anonimowości (ankieta anonimowa, Sztumski 2005: 175). Badaniami objęto większość uczestników pielgrzymki - wszystkich pątników, którzy nie odmówili wypełnienia kwestionariusza ankiety.

Kwestionariusz składał się z 20 pytań oraz metryczki, zawierającej 10 pytań na temat badanych osób. Istotne miejsce w kwestionariuszu zajmowały pytania odnoszące się do zagadnienia motywacji, dlatego też obok pytania o cele (pytanie 15) jakie pielgrzymi zamierzają zrealizować pielgrzymując, zapytano respondentów o intencje - W jakiej intencji pielgrzymujesz? (pytanie 16).

3 Kategorie - ankieta środowiskowa, wyróżniono w ramach podziału ankiet ze względu na sposób rozprowadzenia, pozostałe kategorie to: ankiety prasowe i pocztowe, Sztumski 2005: 172-173. 
Tab. 1. Liczbowa charakterystyka badań ankietowych

\begin{tabular}{|c|c|c|c|c|}
\hline \multirow{2}{*}{ Kategoria danych } & \multicolumn{3}{|c|}{$\begin{array}{c}\text { Rok badań } \\
\text { Numer Pieszej Pielgrzymki Skałecznej }\end{array}$} & \multirow{2}{*}{ Razem } \\
\hline & $\begin{array}{l}2006 \\
X X X\end{array}$ & $\begin{array}{l}2007 \\
X X X I\end{array}$ & $\begin{array}{l}2008 \\
X X X I I \\
\end{array}$ & \\
\hline Liczba pielgrzymów & 279 & 278 & 240 & 797 \\
\hline $\begin{array}{l}\text { Liczba rozdanych } \\
\text { kwestionariuszy }\end{array}$ & 260 & 230 & 223 & 713 \\
\hline $\begin{array}{l}\text { Liczba kwestionariuszy } \\
\text { poddanych analizie }\end{array}$ & $\begin{array}{c}200 \\
(71,7 \%)^{a} \\
(76,9 \%)^{b}\end{array}$ & $\begin{array}{c}172 \\
(61,9 \%) \\
(74,8 \%)\end{array}$ & $\begin{array}{c}207 \\
(86,3 \%) \\
(92,8 \%)\end{array}$ & $\begin{array}{c}579 \\
(72,7 \%) \\
(81,2 \%)\end{array}$ \\
\hline
\end{tabular}

Objaśnienia: a odsetek pielgrzymów uczestniczących w badaniu (w 2006 r. 279 osób - 100\%); b odsetek kwestionariuszy zwróconych, przyjętych do analizy (w 2006 r. 260 ankiet - 100\%).

Źródło: badania własne (kwestionariusz ankiety); liczbę pątników ustalono na podstawie: $2006 \mathrm{r}$. - ASk 2; 2007 r. - Tomoń 2007; 2008 r. - Tomoń 2008.

Uwzględniając kryterium techniczne, pytanie 16. należy do grupy pytań otwartych, których zastosowanie pozwala przede wszystkim na przeprowadzenie jakościowej analizy materiału (Konecki 2000: 37-39). Respondent odpowiadając na pytanie otwarte miał możliwość swobodnej, samodzielnej wypowiedzi, nieskrępowanej sugestiami autora kwestionariusza. Jednocześnie pytanie to posiada cechy charakterystyczne dla pytań sondujących i uzupełniających (Gruszczyński 2003: 33) względem pytania zamkniętego (pytanie 15) odnoszącego się do zamierzeń i pragnień pielgrzymów - celów pielgrzymowania.

Dla zrozumienia i sklasyfikowania motywów postępowania respondentów (pielgrzymów) wykorzystano teorię ugruntowaną (Konecki 2000: 36). Powołując się na jej założenia, dokonano kategoryzacji odpowiedzi na pytanie o intencje pątnicze (pytanie 16). Wyróżniono kryteria o określonych własnościach, według których przypisywano odpowiedzi do utworzonych kategorii. Uzyskane wyniki stały się punktem odniesienia ${ }^{4} \mathrm{w}$ rozważaniach nad celem pielgrzymowania, a w konsekwencji nad ich motywacyjnym aspektem.

4 Ważną cechą teorii ugruntowanej jest fakt, że opracowaną teorię można odnieść do odmiennych obszarów badawczych, formalnych (Glaser 1978: 6). 
Mając świadomość niedoskonałości zastosowanej techniki, a zabiegając o wiarygodne i szczere wypowiedzi, wykorzystano jej szerokie możliwości ${ }^{5}$, poprzez wprowadzenie dwóch pytań tematycznie zbieżnych. Zastosowana metodyka spełniła wcześniejsze założenia. Uzyskanie licznych wypowiedzi na pytanie $15 .^{6}$, umożliwiło rzetelną analizę zagadnienia celu pielgrzymowania, zaś wprowadzenie do kwestionariusza pytania 16., pozwoliło na przeprowadzenie pogłębionej jakościowej analizy zebranego materiału. Uzyskano swobodniejsze, indywidualnie sformułowane, autentyczniejsze odpowiedzi w dosłownym brzmieniu. Wprowadzenie do kwestionariusza, obydwu pytań w zaproponowanej formie (zamkniętej i otwartej), warunkuje pełniejsze zrozumienie skomplikowanego aspektu motywacyjnego. Korzyści wynikające z wykorzystania tak skonstruowanych pytań, wynagrodziły czas poświęcony przygotowaniu pytania 15., zawierającego rozbudowaną (39 propozycji ${ }^{7}$ ) listę alternatywnych odpowiedzi, jak również trud poniesiony na etapie analizy odpowiedzi na pytanie otwarte (numer 16). W niniejszej publikacji ze względu na ograniczoną pojemność przedstawiono indywidualne intencje pątników, jedynie w uzupełnieniu odwołując się do wyników badań dotyczących celów pielgrzymowania. W pracy wykorzystano również informację pozyskane w ramach prowadzonych wywiadów (wywiad swobodny ukierunkowany, jawny) z organizatorami pielgrzymki skałecznej (E. Szumska) i krakowskiej (A. Bac).

\section{Struktura społeczno-demograficzna i geograficzna uczestników pielgrzymki ${ }^{8}$}

Szczegółowe wyniki analizy struktury społeczno-demograficznej respondentów zestawiono w niżej zamieszczonych tabelach (tab. 2, 3, 4, 5). W próbie badawczej

5 Możliwość wykorzystania pytań o zróżnicowanej formie, np. pytań otwartych (technicznie). Wady i zalety stosowania powyższych pytań, dość obszernie przedstawia L.A. Gruszczyński; Gruszczyński 2003: 38-39.

6 W 2006 r. (200 kwestionariuszy), brak odpowiedzi - 0; w 2007 r. (172 kwestionariuszy), brak odpowiedzi - 7; w 2008 r. (207 kwestionariuszy), brak odpowiedzi - 2.

7 Całościowe wyniki analizy zagadnienia celu i motywacji pielgrzymowania opublikowano w: Michalska 2014a: 199-230; kwestionariusz ankiety zamieszczono w: Michalska 2014b: 397; natomiast cząstkowe wyniki zaprezentowano w następującym artykule: Michalska 2008: 96-98.

8 Szczegółową analizę wyników badań odnoszących się do struktury społecznodemograficznej i geograficznej uczestników Pieszej Pielgrzymki Skałecznej (w latach: 1988-2004, 2006-2010) zamieszczono w: Michalska 2014a: 168-186. 
liczącej w sumie 579 osób, zdecydowaną większość stanowiły kobiety (68,7\%). Na każdym etapie badań liczba kobiet przewyższała liczbę pątników płci męskiej. Analizując wiek pielgrzymów biorących udział $w$ badaniu, należy wyróżnić grupe najliczniejszą (25,4\%), deklarującą wiek od 46-55 lat. Również licznie uczestniczyły w pielgrzymce (20,9\%) osoby należące do kolejnego przedziału wiekowego 56-65 lat, tym samym zajmując drugą pozycję wśród całej badanej społeczności. Kobiety żyjące w stanie małżeńskim (34,0\%) oraz panny (25,4\%) liczebnie zdominowały badaną społeczność na każdym z etapów prowadzonych badań. Osoby z wykształceniem wyższym magisterskim $(34,7 \%)$ oraz średnim $(30,4 \%)$ przewyższyły liczbę osób reprezentujących niższy stopień wykształcenia oraz nielicznych respondentów posiadających stopień naukowy. Blisko połowa populacji (48,0\%), to osoby pracujące, dość liczną grupę respondentów stanowili również emeryci $(21,8 \%)$ oraz uczniowie (14,5\%); w roku 2007 wyniki w dwóch powyższych kategoriach były jednakowe (tab. 2).

Spośród osób aktywnych zawodowo najliczniej reprezentowaną grupą byli pracownicy umysłowi i techniczni $(45,8 \%)$. Co ważne, niemal połowę osób włączonych do tej kategorii stanowili nauczyciele ${ }^{9}$. Choć nie zdominowali oni całej populacji pielgrzymów jak to miało miejsce - według Z.S. Jabłońskiego w poprzednich latach istnienia pielgrzymki (Jabłoński 1996: 46), nadal nauczyciele zajmują ważną pozycję w strukturze zawodowej pątników. Do powyższej grupy zawodów wymagających znacznej wiedzy, umiejętności i doświadczenia, zaliczają się również kolejne kategorie: pracownicy administracyjno-biurowi $(22,6 \%)$ oraz kierownicy i specjaliści (4,5\%), szczególnie licznie reprezentowani w 2006 r. (7,0\%). Znaczny odsetek osób stanowią również pielgrzymi pracujący w sektorze usługowym (12,9\%). Warto zwrócić uwagę na fakt, że wśród badanych pielgrzymów niewielki odsetek osób stanowią robotnicy i rzemieślnicy (6,1\%) oraz rolnicy $(0,6 \%)$. Zanotowano również stosunkowo niewielki odsetek pątników prowadzących własną działalność gospodarczą (2,3\%). Wyniki z poszczególnych lat zaprezentowano w tabeli 3 .

Chcąc poznać nie tylko cechy społeczno-demograficzne i religijne badanej społeczności, zapytano respondentów o stosunek pielgrzymów oraz ich rodziców do wiary i praktyk religijnych. Wyniki w poszczególnych latach prowadzonych badań są zbliżone. Niemal wszyscy respondenci, to praktykujący katolicy $(95,7 \%)$.

9 Odsetek nauczycieli w populacji osób aktywnych zawodowo w poszczególnych latach wyniósł: 23,7\% w 2006 r., $28,6 \%$ - 2007 r. i 16,1\% - 2008 r. 


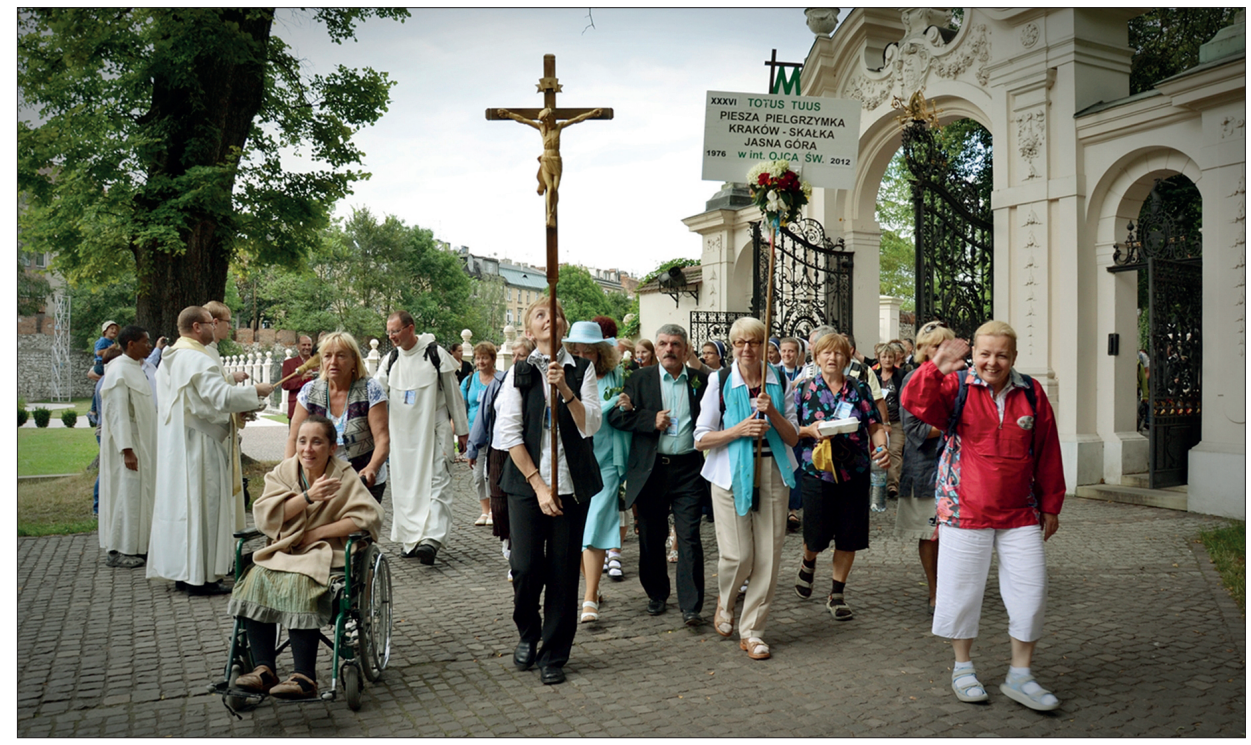

Fot. 1. Tablica pielgrzymkowa 36. Pieszej Pielgrzymki Skałecznej (fot. M. Michalska)

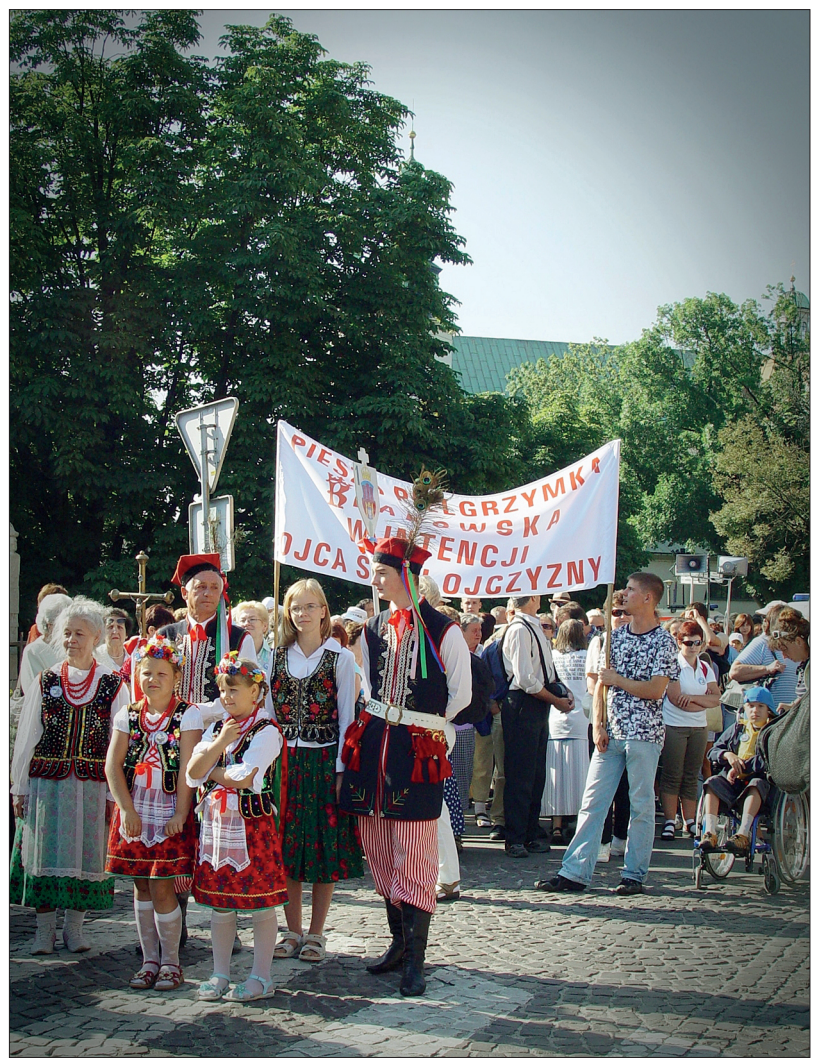

Fot. 2. Piesza Pielgrzymka Krakowska

(fot. M. Michalska) 
Tab. 2. Struktura społeczno-demograficzna pielgrzymów uczestniczących w badaniach

\begin{tabular}{|c|c|c|c|c|c|c|c|c|}
\hline \multirow{3}{*}{$\begin{array}{c}\text { Cechy } \\
\text { demograficzne } \\
\text { i społeczne }\end{array}$} & \multicolumn{8}{|c|}{ Rok } \\
\hline & \multicolumn{2}{|c|}{2006} & \multicolumn{2}{|c|}{2007} & \multicolumn{2}{|c|}{2008} & \multicolumn{2}{|c|}{ 2006-2008 } \\
\hline & $\begin{array}{c}\text { Liczba } \\
\text { osób }\end{array}$ & $\%$ & $\begin{array}{c}\text { Liczba } \\
\text { osób }\end{array}$ & $\%$ & $\begin{array}{l}\text { Liczba } \\
\text { osób }\end{array}$ & $\%$ & $\begin{array}{c}\text { Liczba } \\
\text { osób }\end{array}$ & $\%$ \\
\hline suma & 200 & 100,0 & 172 & 100,0 & 207 & 100,0 & 579 & 100,0 \\
\hline \multicolumn{9}{|l|}{ Płeć } \\
\hline mężczyźni & 59 & 29,5 & 47 & 27,3 & 68 & 32,8 & 174 & 30,1 \\
\hline kobiety & 140 & 70,0 & 120 & 69,8 & 138 & 66,7 & 398 & 68,7 \\
\hline brak danych & 1 & 0,5 & 5 & 2,9 & 1 & 0,5 & 7 & 1,2 \\
\hline \multicolumn{9}{|l|}{ Wiek } \\
\hline poniżej 13 & 8 & 4,0 & 7 & 4,1 & 6 & 2,9 & 21 & 3,6 \\
\hline $13-18$ & 22 & 11,0 & 26 & 15,1 & 17 & 8,2 & 65 & 11,2 \\
\hline $19-25$ & 7 & 3,5 & 17 & 9,9 & 14 & 6,8 & 38 & 6,6 \\
\hline $26-35$ & 20 & 10,0 & 12 & 7,0 & 26 & 12,5 & 58 & 10,0 \\
\hline $36-45$ & 25 & 12,5 & 27 & 15,7 & 22 & 10,6 & 74 & 12,8 \\
\hline $46-55$ & 51 & 25,5 & 39 & 22,6 & 57 & 27,5 & 147 & 25,4 \\
\hline $56-65$ & 50 & 25,0 & 27 & 15,7 & 44 & 21,3 & 121 & 20,9 \\
\hline $66-75$ & 13 & 6,5 & 10 & 5,8 & 17 & 8,2 & 40 & 6,9 \\
\hline powyżej 75 & 3 & 1,5 & 0 & 0,0 & 2 & 1,0 & 5 & 0,9 \\
\hline brak danych & 1 & 0,5 & 7 & 4,1 & 2 & 1,0 & 10 & 1,7 \\
\hline \multicolumn{9}{|l|}{ Stan cywilny } \\
\hline kawaler & 27 & 13,5 & 24 & 13,9 & 24 & 11,6 & 75 & 13,0 \\
\hline panna & 50 & 25,0 & 54 & 31,4 & 43 & 20,7 & 147 & 25,4 \\
\hline żonaty & 31 & 15,5 & 22 & 12,8 & 39 & 18,8 & 92 & 15,9 \\
\hline zamężna & 69 & 34,5 & 55 & 31,9 & 73 & 35,3 & 197 & 34,0 \\
\hline rozwiedziony & 0 & 0,0 & 0 & 0,0 & 2 & 1,0 & 2 & 0,4 \\
\hline rozwiedziona & 7 & 3,5 & 2 & 1,2 & 8 & 3,9 & 17 & 2,9 \\
\hline wdowiec & 1 & 0,5 & 1 & 0,6 & 1 & 0,5 & 3 & 0,5 \\
\hline wdowa & 11 & 5,5 & 8 & 4,7 & 13 & 6,3 & 32 & 5,5 \\
\hline brak danych & 4 & 2,0 & 6 & 3,5 & 4 & 1,9 & 14 & 2,4 \\
\hline \multicolumn{9}{|l|}{$\begin{array}{l}\text { Wykształcenie } \\
\text { Stopień naukowy }\end{array}$} \\
\hline podstawowe & 28 & 14,0 & 34 & 19,7 & 23 & 11,1 & 85 & 14,7 \\
\hline zawodowe & 16 & 8,0 & 13 & 7,6 & 18 & 8,7 & 47 & 8,1 \\
\hline średnie & 61 & 30,5 & 48 & 27,9 & 67 & 32,4 & 176 & 30,4 \\
\hline licencjat/inżynier & 9 & 4,5 & 13 & 7,5 & 13 & 6,3 & 35 & 6,0 \\
\hline magister & 70 & 35,0 & 55 & 32,0 & 76 & 36,7 & 201 & 34,7 \\
\hline doktor & 6 & 3,0 & 2 & 1,2 & 4 & 1,9 & 12 & 2,1 \\
\hline doktor habilitowany & 3 & 1,5 & 0 & 0,0 & 1 & 0,5 & 4 & 0,7 \\
\hline profesor & 1 & 0,5 & 0 & 0,0 & 0 & 0,0 & 1 & 0,2 \\
\hline brak danych & 6 & 3,0 & 7 & 4,1 & 5 & 2,4 & 18 & 3,1 \\
\hline
\end{tabular}




\begin{tabular}{|c|c|c|c|c|c|c|c|c|}
\hline \multirow{3}{*}{$\begin{array}{c}\text { Cechy } \\
\text { demograficzne } \\
\text { i społeczne }\end{array}$} & \multicolumn{8}{|c|}{ Rok } \\
\hline & \multicolumn{2}{|c|}{2006} & \multicolumn{2}{|c|}{2007} & \multicolumn{2}{|c|}{2008} & \multicolumn{2}{|c|}{$2006-2008$} \\
\hline & $\begin{array}{l}\text { Liczba } \\
\text { osób }\end{array}$ & $\%$ & $\begin{array}{l}\text { Liczba } \\
\text { osób }\end{array}$ & $\%$ & $\begin{array}{c}\text { Liczba } \\
\text { osób }\end{array}$ & $\%$ & $\begin{array}{c}\text { Liczba } \\
\text { osób }\end{array}$ & $\%$ \\
\hline suma & 200 & 100,0 & 172 & 100,0 & 207 & 100,0 & 579 & 100,0 \\
\hline \multicolumn{9}{|l|}{ Grupa zawodowa } \\
\hline uczniowie & 30 & 15,0 & 32 & 18,6 & 22 & 10,6 & 84 & 14,5 \\
\hline studenci & 10 & 5,0 & 15 & 8,7 & 18 & 8,7 & 43 & 7,4 \\
\hline pracujący & 98 & 49,0 & 82 & 47,7 & 98 & 47,3 & 278 & 48,0 \\
\hline niepracujący & 2 & 1,0 & 3 & 1,7 & 6 & 2,9 & 11 & 1,9 \\
\hline emeryci & 51 & 25,5 & 32 & 18,6 & 43 & 20,8 & 126 & 21,8 \\
\hline renciści & 4 & 2,0 & 2 & 1,2 & 10 & 4,8 & 16 & 2,8 \\
\hline brak danych & 5 & 2,5 & 6 & 3,5 & 10 & 4,8 & 21 & 3,6 \\
\hline
\end{tabular}

Źródło: badania własne (kwestionariusz ankiety, metryczka).

Tab. 3. Struktura zawodowa aktywnych zawodowo pielgrzymów uczestniczących w badaniach

\begin{tabular}{|l|c|c|c|c|}
\hline \multirow{2}{*}{ Kategorie zawodów } & \multicolumn{4}{|c|}{ Rok } \\
\cline { 2 - 5 } & 2006 & 2007 & 2008 & $2006-2008$ \\
\cline { 2 - 5 } & $\begin{array}{c}\text { Liczba } \\
\text { odp. }{ }^{2}(\%)\end{array}$ & $\begin{array}{c}\text { Liczba } \\
\text { odp. }(\%)\end{array}$ & $\begin{array}{c}\text { Liczba } \\
\text { odp. (\%) }\end{array}$ & $\begin{array}{c}\text { Liczba } \\
\text { odp. }(\%)\end{array}$ \\
\hline pracownicy umysłowi i techniczni & $55(48,3)$ & $47(55,9)$ & $40(35,7)$ & $142(45,8)$ \\
\hline pracownicy administracyjno-biurowi & $23(20,2)$ & $15(17,8)$ & $32(28,6)$ & $70(22,6)$ \\
\hline kadra kierownicza i specjaliści & $8(7,0)$ & $3(3,6)$ & $3(2,7)$ & $14(4,5)$ \\
\hline pracownicy usług & $8(7,0)$ & $12(14,3)$ & $20(17,8)$ & $40(12,9)$ \\
\hline robotnicy i rzemieślnicy & $8(7,0)$ & $2(2,4)$ & $9(8,0)$ & $19(6,1)$ \\
\hline rolnicy & $1(0,9)$ & $0(0,0)$ & $1(0,9)$ & $2(0,6)$ \\
\hline $\begin{array}{l}\text { osoby prowadzące } \\
\text { własną działalność gospodarczą }\end{array}$ & $4(3,5)$ & $1(1,2)$ & $2(1,8)$ & $7(2,3)$ \\
\hline inne & $7(6,1)$ & $4(4,8)$ & $5(4,5)$ & $16(5,2)$ \\
\hline suma & $114(100,0)$ & $84(100,0)$ & $112(100,0)$ & $310(100,0)$ \\
\hline brak odpowiedzi & $16(8,0)$ & $33(19,2)$ & $24(11,6)$ & $73(12,6)$ \\
\hline
\end{tabular}

Objaśnienia: a różnica między liczbą odpowiedzi (liczba odp. $=310$ ) a liczbą respondentów ( $N=579$ ), wynika z faktu, że część osób zadeklarowało więcej niż jeden zawód.

Źródło: badania własne (kwestionariusz ankiety, metryczka). 
Należy jednak zauważyć drugą choć nieporównywalnie mniejszą grupę osób (1,7\%), określających się jako „wątpiący” czy „poszukujący”. Deklarując jakie podejście do wiary oraz praktyk religijnych reprezentują rodzice respondentów, najczęściej wskazywano na kategorię „katolik praktykujący” jednak część pątników, szczególnie w przypadku charakterystyki osoby ojca $(6,9 \%)$ zaznaczyła kategorię „katolik nie praktykujący” (tab. 4).

\subsection{Geograficzny zasięg oddziaływania pielgrzymki}

Jak wykazano, zasięg geograficzny oddziaływania pielgrzymki skałecznej ograniczony jest w dominującej mierze do terytorium Polski. Wyniki analizy omawianego

Tab. 4. Stosunek do wiary i praktyk religijnych deklarowany przez pielgrzymów uczestniczących w badaniach

\begin{tabular}{|c|c|c|c|c|c|c|c|c|}
\hline \multirow{3}{*}{$\begin{array}{l}\text { Stosunek do wiary } \\
\text { i praktyk religijnych }\end{array}$} & \multicolumn{8}{|c|}{ Rok } \\
\hline & \multicolumn{2}{|c|}{2006} & \multicolumn{2}{|c|}{2007} & \multicolumn{2}{|c|}{2008} & \multicolumn{2}{|c|}{$2006-2008$} \\
\hline & $\begin{array}{l}\text { Liczba } \\
\text { osób }\end{array}$ & $\%$ & $\begin{array}{l}\text { Liczba } \\
\text { osób }\end{array}$ & $\%$ & $\begin{array}{l}\text { Liczba } \\
\text { osób }\end{array}$ & $\%$ & $\begin{array}{l}\text { Liczba } \\
\text { osób }\end{array}$ & $\%$ \\
\hline suma & 200 & 100,0 & 172 & 100,0 & 207 & 100,0 & 579 & 100,0 \\
\hline \multicolumn{9}{|l|}{ Pielgrzym } \\
\hline katolik praktykujący & 195 & 97,5 & 161 & 93,6 & 198 & 95,6 & 554 & 95,7 \\
\hline katolik nie praktykujący & 0 & 0,0 & 1 & 0,6 & 0 & 0,0 & 1 & 0,2 \\
\hline innego wyznania & 1 & 0,5 & 0 & 0,0 & 0 & 0,0 & 1 & 0,2 \\
\hline watpiący (poszukujący) & 2 & 1,0 & 3 & 1,7 & 5 & 2,4 & 10 & 1,7 \\
\hline niewierzący & 0 & 0,0 & 1 & 0,6 & 0 & 0,0 & 1 & 0,2 \\
\hline brak danych & 2 & 1,0 & 6 & 3,5 & 4 & 1,9 & 12 & 2,1 \\
\hline \multicolumn{9}{|l|}{ Rodzice: matka } \\
\hline katolik praktykujący & 193 & 96,5 & 156 & 90,7 & 190 & 91,8 & 539 & 93,1 \\
\hline katolik nie praktykujący & 2 & 1,0 & 1 & 0,6 & 4 & 1,9 & 7 & 1,2 \\
\hline innego wyznania & 0 & 0,0 & 0 & 0,0 & 0 & 0,0 & 0 & 0,0 \\
\hline watpiący (poszukujący) & 0 & 0,0 & 0 & 0,0 & 5 & 2,4 & 5 & 0,9 \\
\hline niewierzący & 1 & 0,5 & 0 & 0,0 & 0 & 0,0 & 1 & 0,2 \\
\hline brak danych & 4 & 2,0 & 15 & 8,7 & 8 & 3,9 & 27 & 4,7 \\
\hline \multicolumn{9}{|l|}{ Rodzice: ojciec } \\
\hline katolik praktykujący & 175 & 87,5 & 137 & 79,6 & 164 & 79,2 & 476 & 82,2 \\
\hline katolik nie praktykujacy & 16 & 8,0 & 10 & 5,8 & 14 & 6,8 & 40 & 6,9 \\
\hline innego wyznania & 0 & 0,0 & 1 & 0,6 & 0 & 0,0 & 1 & 0,2 \\
\hline watpiący (poszukujący) & 1 & 0,5 & 2 & 1,2 & 8 & 3,9 & 11 & 1,9 \\
\hline niewierzący & 1 & 0,5 & 1 & 0,6 & 0 & 0,0 & 2 & 0,3 \\
\hline brak danych & 7 & 3,5 & 21 & 12,2 & 21 & 10,1 & 49 & 8,5 \\
\hline
\end{tabular}

Źródło: badania własne (kwestionariusz ankiety, metryczka). 
zagadnienia odnoszące się do województw, w znacznym stopniu zawężają zasięg oddziaływania pielgrzymki do województwa małopolskiego i potwierdzają regionalny charakter pielgrzymki (tab. 5). Większość (78,0\%) respondentów uczestniczących w pielgrzymce, to mieszkańcy województwa małopolskiego, stanowiący od 71,5\% (2007 r.) do 84,5\% (2006 r.) osób. Mieszkańcy Krakowa zdominowali liczebnie społeczność włączoną do omawianego województwa. Spośród pozostałych wymienionych 13 województw, najliczniej reprezentowane były województwa: śląskie (6,0\% pielgrzymów), podkarpackie $(2,4 \%)$ i mazowieckie $(1,9 \%)$.

Tab. 5. Miejsce zamieszkania pielgrzymów uczestniczących w badaniach

\begin{tabular}{|c|c|c|c|c|c|c|c|c|}
\hline \multirow{3}{*}{ Miejsce zamieszkania } & \multicolumn{8}{|c|}{ Rok } \\
\hline & \multicolumn{2}{|c|}{2006} & \multicolumn{2}{|c|}{2007} & \multicolumn{2}{|c|}{2008} & \multicolumn{2}{|c|}{$2006-2008$} \\
\hline & $\begin{array}{c}\text { Liczba } \\
\text { osób }\end{array}$ & $\%$ & $\begin{array}{c}\text { Liczba } \\
\text { osób }\end{array}$ & $\%$ & $\begin{array}{c}\text { Liczba } \\
\text { osób }\end{array}$ & $\%$ & $\begin{array}{c}\text { Liczba } \\
\text { osób }\end{array}$ & $\%$ \\
\hline \multicolumn{9}{|l|}{ Typ miejscowości } \\
\hline miasto $^{a}$ & 160 & 80,0 & 117 & 68,0 & 167 & 80,7 & 444 & 76,7 \\
\hline wieś & 35 & 17,5 & 40 & 23,3 & 28 & 13,5 & 103 & 17,8 \\
\hline brak danych & 5 & 2,5 & 15 & 8,7 & 12 & 5,8 & 32 & 5,5 \\
\hline suma & 200 & 100,0 & 172 & 100,0 & 207 & 100,0 & 579 & 100,0 \\
\hline \multicolumn{9}{|l|}{ Województwo } \\
\hline Małopolskie $^{a}$ & 169 & 84,5 & 123 & 71,5 & 160 & 77,3 & 452 & 78,0 \\
\hline Śląskie & 12 & 6,0 & 11 & 6,4 & 12 & 5,8 & 35 & 6,0 \\
\hline Podkarpackie & 5 & 2,5 & 5 & 2,9 & 4 & 1,9 & 14 & 2,4 \\
\hline Mazowieckie & 0 & 0,0 & 7 & 4,0 & 4 & 1,9 & 11 & 1,9 \\
\hline Wielkopolskie & 3 & 1,5 & 2 & 1,2 & 4 & 1,9 & 9 & 1,5 \\
\hline Łódzkie & 2 & 1,0 & 2 & 1,2 & 0 & 0,0 & 4 & 0,7 \\
\hline Świętokrzyskie & 1 & 0,5 & 4 & 2,3 & 1 & 0,5 & 6 & 1,0 \\
\hline Kujawsko-pomorskie & 1 & 0,5 & 2 & 1,2 & 1 & 0,5 & 4 & 0,7 \\
\hline Lubuskie & 1 & 0,5 & 1 & 0,6 & 0 & 0,0 & 2 & 0,4 \\
\hline Pomorskie & 1 & 0,5 & 0 & 0,0 & 0 & 0,0 & 1 & 0,2 \\
\hline Lubelskie & 1 & 0,5 & 0 & 0,0 & 4 & 1,9 & 5 & 0,8 \\
\hline Zachodnio-pomorskie & 0 & 0,0 & 1 & 0,6 & 1 & 0,5 & 2 & 0,4 \\
\hline Opolskie & 0 & 0,0 & 1 & 0,6 & 0 & 0,0 & 1 & 0,2 \\
\hline Dolnośląskie & 0 & 0,0 & 0 & 0,0 & 2 & 1,0 & 2 & 0,4 \\
\hline brak danych & 3 & 1,5 & 12 & 6,9 & 12 & 5,8 & 27 & 4,7 \\
\hline zagranica & 1 & 0,5 & 1 & 0,6 & 2 & 1,0 & 4 & 0,7 \\
\hline
\end{tabular}

Objaśnienia: a większość respondentów zadeklarowało jako miejsce zamieszkania miasto Kraków: 105 osób - 62,1\% (2006 r.), 67 osób - 54,5\% (2007 r.), 96 osób - 60,0\% (2008r.).

Źródło: badania własne (kwestionariusz ankiety, metryczka). 


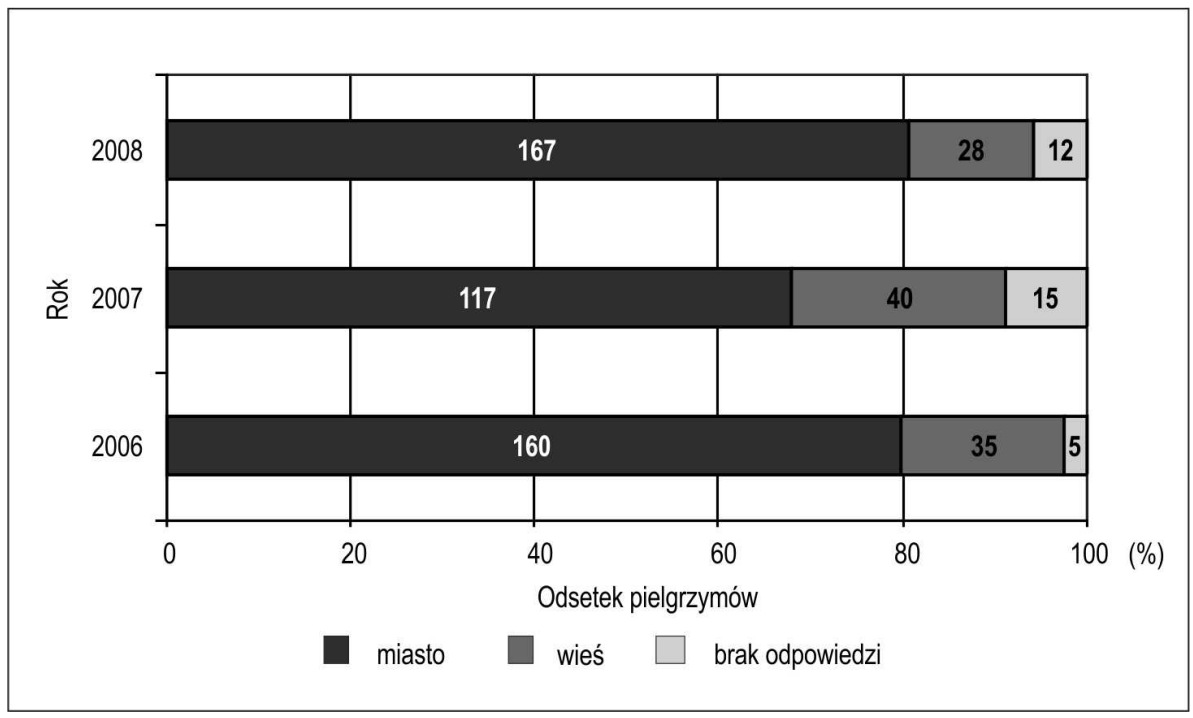

Ryc. 2. Miejsce zamieszkania pielgrzymów uczestniczących w badaniu Źródło: badania własne (kwestionariusz ankiety, metryczka).

Mieszkańcy miast uczestniczący w Pieszej Pielgrzymki Skałecznej w latach: 2006-2008, zdominowali liczebnie pielgrzymów zamieszkujących tereny wiejskie. Aż 76,7\% respondentów pochodziło z miast. Mniej liczna grupa stanowiąca 17,8\% pątników zadeklarowała jako miejsce zamieszkania miejscowości wiejskie (tab. 5, ryc. 2).

\section{Intencje uczestników Pieszej Pielgrzymki Skałecznej}

Pielgrzymi skałeczni poproszeni o wymienienie intencji, w jakiej podjęli się pielgrzymować zdecydowanie najczęściej wskazywali intencje błagalne. W sumie w latach 2006-2008, 477-krotnie deklarowano, że wyruszono na szlak by wypraszać u Boga różnorodne łaski dla siebie, najbliższej rodziny, przyjaciół oraz osób im nie znanych, potrzebujących modlitewnego wsparcia. Dla znacznej grupy pątników (172 odpowiedzi) pielgrzymowanie przybrało formę dziękczynienia. Niewielu jednak (30 odpowiedzi) wyruszało na szlak pątniczy w intencji pokutnej. Jeszcze mniejsza grupa pielgrzymów (19 odpowiedzi) deklarowała inne niż wyżej 
wymienione, powszechnie znane intencje. Przede wszystkim, więc uczestniczenie w pielgrzymce stało się sposobnością do ujawnienia wszelkich trosk i słabości, wymodlenia wsparcia i opieki jak również wyrażenia wdzięczności i uwielbienia Boga. W tabeli 6. przedstawiono ilościową charakterystykę wyróżnionych kategorii intencji, w kolejnych tabelach (tab. 7, 8, 9) zaprezentowano szczegółowe wyniki analizy.

Najliczniejsza grupa respondentów (110 odpowiedzi) ujawniając swe intencje błagalne wymieniała zdrowie, jako dobro szczególnie cenne dla siebie i bliskich, proszono o uzdrowienie, pomoc w uwolnieniu od nałogów. Niemal równie ważne okazały się dla pątników trzy kolejne kategorie intencji (każdej przypisano po około 70 odpowiedzi). Modlono się o pogłębienie wiary, umocnienie duchowe, świętość życia jak również nawrócenie dzieci, współmałżonków, wnuków i samych pątników. Proszono o „(...) błogosławieństwo Boże w rodzinie (...)” oraz „(...) dalszą opiekę (...)” w życiu pielgrzymów i ich bliskich. Równie często proszono o różnorodne „(...) Bogu wiadome łaski (...)”. Pielgrzymując modlono się o „(...) uleczenie relacji rodzinnych (...)”, pomoc w rozwiązaniu trudnych życiowych problemów, ale i siłę w przezwyciężeniu grzechu, swych słabości (43 odpowiedzi). Część pątników (28 odpowiedzi) zwracając się do Boga

Tab. 6. Ilościowy rozkład wyników dla głównych kategorii intencji

\begin{tabular}{|c|c|c|c|c|}
\hline \multirow{2}{*}{ Kategoria intencji } & \multicolumn{4}{|c|}{ Rok } \\
\cline { 2 - 5 } & 2006 & 2007 & 2008 & $2006-2008$ \\
\cline { 2 - 5 } & Liczba odp. $^{\text {a }}$ & Liczba odp. & Liczba odp. & Liczba odp. \\
\hline Intencje błagalne & 171 & 112 & 194 & 477 \\
\hline Intencje dziękczynne & 56 & 53 & 63 & 172 \\
\hline Intencje pokutne & 16 & 6 & 8 & 30 \\
\hline Pozostałe intencje & 7 & 3 & 9 & 19 \\
\hline Suma & 250 & 174 & 274 & 698 \\
\hline
\end{tabular}

Objaśnienia: a Różnica między liczbą odpowiedzi (liczba odp. $=698$ ) a liczbą respondentów $(\mathrm{N}=579)$, wynika $z$ budowy pytania - pielgrzymi odpowiadając na pytanie otwarte mogli podać więcej niż jedną intencję.

Źródło: badania własne (kwestionariusz ankiety, pytanie 16). 
wyrażało pragnienie poznania swego powołania i wytrwanie w nim, odnalezienie właściwej drogi życiowej. Rodzice oraz sami studenci i młodzież prosili o zdanie egzaminów, szczęśliwe ukończenie studiów jak również znalezienie dobrej pracy (27 odpowiedzi). Wybrani pielgrzymi (18 odpowiedzi) wyruszali na szlak pątniczy w intencji pogłębienia i utrzymania „(...) miłości w rodzinie (...)”, zgody i przyjaźni. Proszono o dar macierzyństwa i ojcostwa oraz szczęśliwe rozwiązanie dla córek, synowych i przyjaciółek (14 odpowiedzi). W roku 2007 oraz 2008 jedynie sześciokrotnie wspominano w intencjach osoby zmarłe. Spośród pozostałych intencji błagalnych, jakie pielgrzymi wymienili (20 odpowiedzi) znalazły się prośby o: pokój na świecie, „(...) lepszą szczęśliwą przyszłość (...)”, siłę przetrwania, „(...) łaskę następnej pielgrzymki (...)” oraz modlitwy składane „(...) za ofiary gwałtów i morderstw (...)" (tab. 7).

Pielgrzymi skałeczni wskazując na intencję dziękczynne najczęściej (62 odpowiedzi) deklarowali, że pragną podziękować za wszelkie łaski „Bogu wiadome”. W przypadku pozostałych intencji dziękczynnych znacznie chętniej ujawniano ich pełną treść. Wielokrotnie (38 odpowiedzi) poprzez pielgrzymowanie pątnicy dziękowali za dar drugiego człowieka. Analizując wypowiedzi z tej kategorii należy wyróżnić trzy rodzaje wypowiedzi. Dziękowano za trwałość związku małżeńskiego i rodzinę, dar macierzyństwa i ojcostwa, szczęśliwe rozwiązanie, obecność wspaniałych ludzi (szczególnie członków najbliższej rodziny) w życiu codziennym pątników. Nieco rzadziej (24 odpowiedzi) dziękowano za zdrowie, uleczenie z ciężkiej choroby, ocalenie życia, udaną operację jak również „(...) uwolnienie z nałogu (...)" alkoholowego lub narkotykowego. Pielgrzymi wyrażali również swą wdzięczność (14 odpowiedzi) za zdane egzaminy, ukończenie studiów, znalezienie pracy oraz „(...) przejście na emeryturę (...)” wieńczącą wieloletni wysiłek zawodowy. Dziękując za różnorodne życiowe doświadczenia respondenci wyrażali wdzięczność za „(...) wszystkie dobre i złe chwile (...)”, zarówno za oczywiste dobrodziejstwa jak i te trudne, bolesne zdarzenia i sytuacje, które ostatecznie umacniają i zbliżają do Boga (14 odpowiedzi). W drodze na Jasną Górę składano również podziękowanie (7 odpowiedzi) za wiarę i nawrócenie, „(...) dar nowego życia - rozwój duchowy (...)”, sakramenty święte oraz obecność Boga. Pielgrzymi wyrażali dziękczynienie za „(...) Bożą opiekę (...)” roztaczaną nad nimi oraz najbliższymi członkami ich rodzin (6 odpowiedzi). Wędrówka pątniczym szlakiem stała się formą dziękczynienia za pomoc w trudnych sytuacjach życiowych, wieloletnie istnienie pielgrzymki skałecznej oraz „(..) kanonizacje 
Tab. 7. Wykaz intencji błagalnych zadeklarowanych przez pielgrzymów

\begin{tabular}{|c|c|c|c|c|}
\hline \multirow{3}{*}{$\begin{array}{l}\text { Intencja błagalna, } \\
\text { prośba o: }\end{array}$} & \multicolumn{4}{|c|}{ Rok } \\
\hline & 2006 & 2007 & 2008 & $2006-2008$ \\
\hline & Liczba odp. ${ }^{a}$ & Liczba odp. & Liczba odp. & Liczba odp. \\
\hline Zdrowie (uzdrowienie) & 39 & 27 & 44 & 110 \\
\hline Wiarę i nawrócenie & 25 & 12 & 34 & 71 \\
\hline Błogosławieństwo, Bożą opiekę & 31 & 14 & 25 & 70 \\
\hline Łaskę Bożą & 19 & 24 & 27 & 70 \\
\hline Pomoc w trudnych doświadczeniach & 22 & 10 & 11 & 43 \\
\hline $\begin{array}{l}\text { Rozeznanie i wytrwanie } \\
\text { w powołaniu }\end{array}$ & 9 & 8 & 11 & 28 \\
\hline Dar pracy, zdanie egzaminów & 9 & 6 & 12 & 27 \\
\hline Miłość & 7 & 1 & 10 & 18 \\
\hline $\begin{array}{l}\text { Szczęśliwe rozwiazzanie } \\
\text { (łaskę macierzyństwa i ojcostwa) }\end{array}$ & 4 & 2 & 8 & 14 \\
\hline Zbawienie zmarłych & 0 & 3 & 3 & 6 \\
\hline Inne & 6 & 5 & 9 & 20 \\
\hline Suma & 171 & 112 & 194 & 477 \\
\hline
\end{tabular}

Objaśnienia: a różnica między liczbą odpowiedzi (liczba odp. $=477$ ) a liczbą respondentów $(\mathrm{N}=579)$, wynika $\mathrm{z}$ budowy pytania - pielgrzymi odpowiadając na pytanie otwarte mogli podać więcej niż jedną intencję.

Źródło: badania własne (kwestionariusz ankiety, pytanie 16).

św. Jadwigi (...)”. Szczegółową ilościową charakterystykę intencji dziękczynnych przedstawiono w tabeli 8 .

W intencjach pokutnych pielgrzymowało stosunkowo niewielu pątników, w sumie w latach 2006-2008 jedynie 30 odpowiedzi wskazywało na pokutny charakter pielgrzymowania. Ponadto, pielgrzymi niechętnie zdradzali pełną treść swych intencji. Przede wszystkim poprzez uczestnictwo w pielgrzymce „(..) odpokutowywano winy (...)", składano przeprosiny. Ponadto też, uczestnicy pielgrzymki w 2006 r. poszukiwali przebaczenia, wyrażali żal za popełnione grzechy, poprzez pątniczy trud pragnęli zadośćuczynić Bogu za popełnione zło (16 odpowiedzi). 
Tab. 8. Wykaz intencji dziękczynnych zadeklarowanych przez pielgrzymów

\begin{tabular}{|l|c|c|c|c|}
\hline \multirow{2}{*}{$\begin{array}{c}\text { Pielgrzymowanie jako } \\
\text { dziękczynienie za: }\end{array}$} & 2006 & 2007 & 2008 & $2006-2008$ \\
\cline { 2 - 5 } & Liczba odp. ${ }^{\text {a }}$ & Liczba odp. & Liczba odp. & Liczba odp. \\
\hline Wszelkie otrzymane łaski & 23 & 20 & 19 & 62 \\
\hline Dar drugiego człowieka & 15 & 5 & 18 & 38 \\
\hline Zdrowie (uzdrowienie) & 7 & 8 & 9 & 24 \\
\hline Dar pracy, zdane egzaminy & 3 & 8 & 3 & 14 \\
\hline Wszelkie życiowe doświadczenia & 4 & 3 & 7 & 14 \\
\hline Wiarę i nawrócenie & 1 & 4 & 2 & 7 \\
\hline Bożą opiekę & 1 & 3 & 2 & 7 \\
\hline Inne & 2 & 2 & 3 & 172 \\
\hline
\end{tabular}

Objaśnienia: a różnica między liczbą odpowiedzi (liczba odp. $=172)$ a liczbą respondentów $(\mathrm{N}$ = 579), wynika z budowy pytania - pielgrzymi odpowiadając na pytanie otwarte mogli podać więcej niż jedną intencję.

Źródło: badania własne (kwestionariusz ankiety, pytanie 16).

Intencje błagalne i dziękczynne wyraźnie dominują nad pozostałymi, zadeklarowanymi przez pątników intencjami. Jednak poza wyżej wspomnianymi intencjami pokutnymi można wyróżnić 11 pozostałych rodzajów intencji, wskazywanych przez nielicznych respondentów. Podjęli oni trud pątniczej wędrówki w intencji: uwielbienia Boga, umocnienia swej wiary, ,(...) zrozumienia minionych doświadczeń (...)” i siebie samego, by „(...) dać świadectwo swoją postawą (...)” zachęcając innych do pielgrzymowania. Wędrowano w intencji zawierzenia siebie i rodziny Matce Bożej, aby „(...) doświadczyć Boskiej obecności (...), (...) otaczać innych i być otoczonymi modlitwą (...)” oraz doświadczyć Boga we wspólnocie Kościoła, odnaleźć Boga, służyć Mu, poznać Jego naukę i ofiarować swój trud w intencji Kościoła. Ilościową charakterystykę wymienionych intencji przedstawiono poniżej, w tabeli 9. 
Tab. 9. Wykaz pozostałych intencji zadeklarowanych przez pielgrzymów

\begin{tabular}{|c|c|c|c|c|}
\hline \multirow{3}{*}{ Pielgrzymuję w intencji: } & \multicolumn{4}{|c|}{ Rok } \\
\hline & 2006 & 2007 & 2008 & 2006-2008 \\
\hline & Liczba odp. ${ }^{a}$ & Liczba odp. & Liczba odp. & Liczba odp. \\
\hline Odpokutowania win & 16 & 6 & 8 & 30 \\
\hline Uwielbienia Boga & 2 & 0 & 1 & 3 \\
\hline Umocnienia wiary & 0 & 0 & 3 & 3 \\
\hline By zrozumieć przeszłość i siebie & 2 & 0 & 0 & 2 \\
\hline By dać świadectwo wiary & 0 & 1 & 1 & 2 \\
\hline Oddać się w opiekę Matce Bożej & 1 & 0 & 1 & 2 \\
\hline By obcować z Bogiem & 0 & 0 & 2 & 2 \\
\hline Modlić się we wspólnocie & 0 & 1 & 0 & 1 \\
\hline Odnaleźć Boga & 0 & 1 & 0 & 1 \\
\hline By złożyć ofiarę za Kościół & 1 & 0 & 0 & 1 \\
\hline By służyć Bogu & 1 & 0 & 0 & 1 \\
\hline Poznać naukę Boga & 0 & 0 & 1 & 1 \\
\hline Suma & 23 & 9 & 17 & 49 \\
\hline
\end{tabular}

Objaśnienia: a różnica między liczbą odpowiedzi (liczba odp. $=49$ ) a liczbą respondentów $(\mathrm{N}$ = 579), wynika z budowy pytania - pielgrzymi odpowiadając na pytanie otwarte mogli podać więcej niż jedną intencję.

Źródło: badania własne (kwestionariusz ankiety, pytanie 16).

\section{Podsumowanie}

Dla pielgrzymów skałecznych intencja w jakiej pątnicy pielgrzymowali na Jasną Górę przybrała niemal wyłącznie charakter religijny. Forma pytania otwartego pozwoliła wykazać wyraźną dominację intencji błagalnych (477 odpowiedzi), drugą grupą intencji najczęściej wymienianych przez pielgrzymów okazały się intencje dziękczynne (172 odpowiedzi). Potrzebę pokuty ujawnili nieliczni pielgrzymi (30 odpowiedzi). Intencje poza religijne wymieniano niezwykle rzadko, choć 
warto przypomnieć, że gdy zaproponowano pątnikom (w innej części kwestionariusza) do wyboru cele o charakterze świeckim, pielgrzymi wskazywali na chęć realizacji również takich potrzeb poprzez pielgrzymowanie (Michalska 2008: 87-102, Michalska 2014a: 211-224). Dlatego też dopiero zestawienie wyników opinii badanych dotyczących intencji (pytanie 16) i celów (pytanie 15), pozwala nakreślić pełniejszy obraz dążeń i motywacji, determinujących aktywność pątniczą uczestników pielgrzymki skałecznej. Analiza odpowiedzi na obydwa z wyżej wymienionych pytań jednoznacznie wskazuje na dominacje intencji ale i celów o charakterze religijnym. Uznano, że ich realizacja umożliwia zaspokojenie $\mathrm{m}$. in. potrzeby bezpieczeństwa i samorealizacji (Madsen 1980: 434, 438, Maslow 1990: 76, 80, 86, Maslow 2004: 31, Michalska 2008: 94-95, Michalska 2014a: 214-215, 220-221). Zgodnie z humanistyczną koncepcją motywacji autorstwa amerykańskiego psychologa A. Maslowa, powyższe dążenia zajmują niezwykle ważne miejsce w hierarchii potrzeb ludzkich. Wyniki prowadzonych badań wskazują, że mogą być one zaspokajane poprzez pielgrzymowanie. Jednocześnie wykazano, że motywacja religijna nadal stanowi najsilniejszy bodziec warunkujący ciągłość istnienia i rozwój pieszego ruchu pątniczego. Na koniec warto zaznaczyć, że nie wszyscy pątnicy pielgrzymują w konkretnej intencji ${ }^{10}$. Dla pewnej grupy osób ${ }^{11}$ zasadnicze znaczenie ma sam akt pielgrzymowania.

\section{Podziękowania}

Składam serdeczne podziękowania moim rozmówcom za życzliwość i przekazane informację. Elżbieta Szumska - absolwentka Duszpasterstwa Akademickiego Skałka, uczestniczka Pieszej Pielgrzymki Skałecznej od 1976 r. (przez ok. 29 lat), współorganizator pielgrzymki, nazywana przez pątników „Matką pielgrzymki”.

Andrzej Bac - współorganizator (jako przewodniczący Rady Duszpasterstw Akademickich powołanej przez Karola Wojtyłę w 1977 r.) Białego Marszu w 1981 r.

${ }^{10}$ Powyższą opinię potwierdza również dziennikarka Radia Kraków Anna Kluz-Łoś, prowadząca liczne rozmowy z pielgrzymami wędrującymi różnymi szlakami pątniczymi wiodącymi do Częstochowy jak i do Santiago de Compostela. Zdaniem dziennikarki, często „(...) idzie się żeby być w drodze i ta droga jest (...) bardzo ważna (...)”; wywiad 3.

${ }^{11} \mathrm{~W}$ prowadzonych badaniach ankietowych każdorazowo o braku intencji informował co najmniej jeden pielgrzym (w 2006 r. - 1 odpowiedź, w 2007 r. - 1 odpowiedź, w 2008 r. -2 odpowiedzi). 
Od 1981 r. współorganizator, współcześnie koordynator Pieszej Pielgrzymki Krakowskiej. Konsulator Rady ds. Apostolstwa Świeckich Konferencji Episkopatu Polski, zastępca dyrektora wykonawczego oraz przewodniczący sekcji logistyki komitetu organizacyjnego Światowych Dni Młodzieży Kraków 2016.

\section{Literatura}

\section{Materiały archiwalne}

\section{Archiwum klasztoru Ojców Paulinów na Skałce w Krakowie (ASk)}

ASk 1: Zaproszenie na październikowe spotkanie popielgrzymkowe, 1988, ASk, brak sygnatury.

ASk 2: Zeszyt zapisów uczestników Pieszej Pielgrzymki Skałecznej, 2006, ASk, brak sygnatury.

\section{Publikacje}

Balon Z., Samsonowska K., 1996, Piesza Pielgrzymka Krakowska na Jasna Górę, „Peregrinus Cracoviensis”, 4, s. 59-72.

Glaser B., 1978, Theoretical Sensitivity, CA: Sociology Press, San Francisco.

Gruszczyński L.A., 2003, Kwestionariusze w socjologii. Budowa narzędzi do badań surveyowych, Wydawnictwo Uniwersytetu Śląskiego, Katowice.

Gubała J., Krajewska A., Bac A., 2002, Piesza Pielgrzymka Krakowska na Jasną Górę 1981-2001, Parafia Rzymsko-Katolicka Św. Jana Chrzciciela, Kraków.

Jabłoński Z. S., 1996, Piesza pielgrzymka ze Skałki w Krakowie na Jasną Górę, „Peregrinus Cracoviensis”, 4, s. 39-57.

Katechizm Kościoła Katolickiego, 1994, Wydawnictwo Pallottinum, Poznań.

Konecki K. T., 2000, Studia z metodologii badań jakościowych. Teoria ugruntowana, Wydawnictwo Naukowe PWN, Warszawa.

Madsen K. B., 1980, Współczesne teorie motywacji. Naukoznawcza analiza porównawcza, Państwowe Wydawnictwo Naukowe, Warszawa.

Maslow A. H., 1990, Motywacja i osobowość, Wydawnictwo Naukowe PWN, Warszawa.

Maslow A. H., 2004, W stronę psychologii istnienia, Dom Wydawniczy REBIS, Poznań. 
Michalska M., 2008, Cele i motywy pielgrzymowania z Krakowa na Jasna Górę na przykładzie XXXI Pieszej Pielgrzymki Skałecznej, „Peregrinus Cracoviensis”, 19, s. 87-102.

Michalska M., 2014a, Społeczno-geograficzne uwarunkowania pieszego pielgrzymowania z Krakowa na Jasna Górę (na przykładzie Pieszej Pielgrzymki Skałecznej), rozprawa doktorska w archiwum Instytutu Geografii i Gospodarki Przestrzennej Uniwersytetu Jagiellońskiego, cz.1, Kraków.

Michalska M., 2014b, Społeczno-geograficzne uwarunkowania pieszego pielgrzymowania z Krakowa na Jasna Górę (na przykładzie Pieszej Pielgrzymki Skałecznej), rozprawa doktorska w archiwum Instytutu Geografii i Gospodarki Przestrzennej Uniwersytetu Jagiellońskiego, cz. 2, Kraków.

Reber A. S., Reber E. S., 2005, Stownik Psychologii, Wydawnictwo Naukowe Scholar, Warszawa.

Sztumski J., 2005, Wstęp do metod i technik badań społecznych, „Śląsk” Sp. z o.o. Wydawnictwo Naukowe, Katowice.

Tomoń S., 2007, Szli w upale, ze Skatki w Krakowie..., Biuro Prasowe Jasnej Góry, http://www.jasnagora.com/wydarzenieDuze.php?ID=3000 (dostęp: 06.04.2016).

Tomoń S., 2008, Pieszo Jura, ze Skałki w Krakowie, Biuro Prasowe Jasnej Góry, http://www.jasnagora.com/wydarzenieDuze.php?ID=3982 (dostęp: 06.04.2016).

Władyczanka M., 1993, Pielgrzymkowe szlaki, [w:] Z. S. Jabłoński (red.), Pątniczym szlakiem Orlich Gniazd, Wydawnictwo Zakonu Paulinów PAULINIANUM, Jasna Góra - Częstochowa, s. 11-18.

\section{Wykaz wywiadów (archiwum prywatne)}

wywiad 1: wywiad z Bac A. (przeprowadzono: 27.02.2012).

wywiad 2: wywiad z Szumską E. (przeprowadzono: 04.05.2012).

wywiad 3: wywiad przeprowadzony przez A. Kluz-Łoś w ramach programu Radia Kraków - „Duchowe Wędrówki” (przeprowadzono: sierpień 2010, archiwum Radia Kraków).

\section{Strony internetowe}

www 1: Sanktuarium Męczeństwa Św. Stanisława na Skałce, Pielgrzymka Skałeczna, http://www.skalka.paulini.pl/page,30.html (dostęp: 06.04.2016).

www 2: Piesza Pielgrzymka Krakowska, List Metropolity Krakowskiego na XXX Krakowską Pielgrzymkę Piesza na Jasna Górę, http://pielgrzymkakrakowska.diecezja. $\mathrm{pl} /$ index.php?option=com_content\&view $=$ article\&id=557:list-metropolity-krakowski ego\&catid=4:aktualnoci\&Itemid=2 (dostęp: 02.01.2012).

Marta Michalska, dr

Kraków, marta.michalska@tlen.pl 